\title{
Standard Javanese Causatives in online editorials and short stories
}

Noor Malihah

State Institute for Islamic Studies (STAIN) Salatiga

Jl. Tentara Pelajar no. 2 Salatiga

noormalihah_itah@yahoo.com

\begin{abstract}
This paper explores the distinctive features of the standard Javanese causatives in on-line editorials and short stories.

This research is based on written corpus. This written corpus was compiled from articles published in an online newspaper Solo Pos. To analyze the corpus, I have developed a system of manual annotation to identify the features of verb transitivity, the animacy and humanness of the verb, the presence of active, passive and ergative-like clauses and the number of other grammatical and semantic features using a system of tags.

Using this annotation, I analyze the data based on dua anlaysis: genre analysis, functional analysis using a quantitative method.

The findings show that genre influences the selection of causative types (markers). Also, there exists gawe used as a verb of causation in both editorials and short stories which contradicts to the canonical rule of the Javanese active verb and Malihah's (2014) findings. The finding also shows that the standard Javanese causative in online editorials and short stories occurs with intransitive verbs. The last finding is that active clause is the relative prominent type of clause which occurs in all marker. In conclusion, the above findings have made contributions to knowledge to Javanese grammar.
\end{abstract}

Keyword: Javanese, causatives, causation types, genre 


\section{Abstrak}

Artikel ini mendiskusikan tentang fitur pembeda pada causative bahasa Jawa standar di kolom editorial dan cerita pendek pada media online. Penelitian ini bersumber pada korpus tertulis. Korpus tertulis ini dikumpulkan dengan mengkompilasi beberapa artikel yang diterbitkan pada surat kabar local online Solo Pos. Untuk menganalisis korpus ini, peneliti mengembangkan system anotasi manual untuk mengidentifikasi fitur-fitur transitivitas verba, animacy dan humanness dari verba, penggunaan kalimat aktif, pasidan ergative-like dan mengidentifikasi jumlah fitur gramatikal dan semantis lainnya dengan menggunakan sistem pengkodean.

Dengan menggunakan anotasi ini, peneliti menganalisis data melalui tiga analisis, yaitu analisis genre dan analisis fungsional dengan metode kuantitatif.

Temuan dalam penelitian ini menunjukkan bahwa genre mempengaruhi pemilihan jenis kausatif yang digunakan. Penelitian ini juga mendapatkan fenomena bahwa kata gawe digunakan sebagai verba pengkausatif pada editorial dan cerita pendek yang bertentangan dengan aturan umum verba aktif dalam bahasa Jawa dan juga temuan Malihah (2014). Temuan dalam penelitian ini juga menunjukkan bahwa kausatif bahasa Jawa standar pada editorial dan cerita pendek dalam media online ini hanya terjadi pada verba intransitive. Temuan terakhir dalam penelitian ini adalah bahwa klausa aktif adalah klausa yang paling menonjol penggunaannya pada semua tipe kausatif bahasa Jawa.

Kesimpulannya adalah bahwa temuan-temuan dalam penelitian ini memberikan kontribusi keilmuan dalam bahasa Jawa.

Keywords: Bahasa Jawa, Kausatif, Tipe Kausatif, genre

\section{Introduction}

Javanese verbal morphology is rich; however, it is understudied, for example Javanese causative, Javanese applicative and Javanese passive constructions. Javanese speakers are mostly bilingual in Indonesian and Javanese. The official language in Indonesia is Indonesian. Indonesian is used in some official situations, for example in 
court, in school, in a governmental office, at a wedding party and so on. Indonesian is also used as a lingua franca when Javanese speakers communicate to other ethnics in Indonesian. Being bilingual, Javanese speakers have a tendency to use more Indonesian rather than Javanese. Javanese is less favoured than Indonesian and is less prestigious (Rukiah 2010: 82; Rahayu and Listiyorini 2013: 122-3). Using Javanese instead of Indonesian is also a mark of a lack of education (Smith-Hefner 2009: 59). Javanese speakers speaking Javanese is also considered to have a lower status in society (Rahayu and Listiyorini 2013: 132). This situation leads to the Javanese speakers not to learn and use Javanese but Indonesian. As a result, there are very few studies on Javanese. Due to this reason, it is necessary to conduct a research on Javanese to preserve the language.

In addition to the above reason, it is also worthy to look at Javanese language since it has some distinctive features crosslinguistically. There are several features of a language which can be investigated, for example lexicon, phonology, morphology and syntax. To identify such as lexical and phonological features are easy. However it needs more effort to distinguish some morphological and syntactical differences (Sudaryanto et al. 1991 and see e.g. Hollmann and Siewierska, 2006: 22).

One feature that I would like to discuss in this article is Javanese causative constructions. The Javanese causatives are very much among the aspects of the grammar that are understudied. As noted above, a critical point to be aware of, and one that makes the Javanese causative perhaps unusual, is that the causatives are another use of the same 
morphemes that mark the applicative ${ }^{1}$. Therefore, there is no separate causative morphology. Conners (2008: 214) argues that the causative is a function of the Javanese applicatives. He does not distinguish the applicative and the causative as separate constructions. However, he notes that in many languages, causatives tend to behave differently from applicatives, and have unique morphology. Other authors have treated the causative separately to the applicative, and I will do likewise. In the following paragraphs, I will discuss an overview of a causative construction, models of causation and the Javanese causative construction.

Causative constructions have been an important focus of study in many areas of linguistics (Comrie 1989: 165). Comrie suggests that causatives are important because they involve some complex interactions among semantics, syntax, and morphology. Several definitions of causative have been proposed by some linguists. However, there is no precise definition of a causative is taken. Comrie (1989) argues that in a causative, a new argument, an entity who causes the action or event to take place, is added as the clause subject. Thus, the function of a causative construction is to encode the semantics of causation. A simple example of an English causative is shown in (1b) and the equivalent noncausative is in (1a).

(1) a. John left the room.

b. The man caused John to leave the room.

\footnotetext{
${ }^{1}$ Haspelmath and Bardey (2004: 1134) describe the applicative as a valency-increasing phenomenon where a direct object is added to a verb. Applicatives give the status of a direct object to oblique noun phrases of different kinds.
} 
Causatives involve two events (in the broadest sense of event): (i) the causing event, in which a causer does something to cause the occurrence of the caused event and (ii) the caused event, in which a causee performs an action in consequence of the causing event (Shibatani 1976: 1-2; Comrie 1989: 165; Dixon 2000: 30). In this situation, a causer is someone or something that controls an activity, while a causee is someone or something that does an action controlled by the causer. Thus, without the causation, the effect would not have occurred. However, there is a situation in which the caused event does not necessarily come about. For example, Shibatani illustrates such a causative as in I told John to go which may be followed by a clause but he actually didn't go. This causative is different from I made John go which the caused event took place. To accommodate these two causatives, linguists often use the terms non-implicative and implicative causative respectively. Many studies on causatives only consider implicative causatives, and I will also restrict myself to considering implicative causatives.

Having discussed the definition of causatives, I will now turn to discuss models of causation. Talmy (1972, 1976, 1985, 1988, 2000) discusses a lot about models of causation. Talmy (1985, cited in Croft 1991: 166-7) points out that 'causation is the relation between events, but he argues that the relevant classification of causation types is based on the status of and change in the entities that participate in the event'. Causation is seen as an instance of force dynamic interaction ${ }^{2}$. Talmy (2000: 414) introduces a system of diagramming to represent different

\footnotetext{
${ }^{2}$ Read further about the concept of force dynamics in Talmy (2000).
} 
patterns within this framework of force dynamics. Based on this understanding, Talmy distinguishes causation types based on what type of entity is acting on what other type of entity (i.e. physical entity or mental entity) as listed in (2)

(2) Talmy's causation types (after Talmy 1972, 1976, cited in Croft 1991: 166)

a. Physical causation : physical object acting on physical object

b. Volitional causation : volitional entity acting on physical object

c. Affective causation : physical object acting on entity with mental state

d. Inducive causation : volitional entity acting on entity with mental state.

A 'volitional entity' in (2) is possible to be considered the same thing as an 'entity with mental state' (Croft 2012: 202). Then, the animacy hierarchy ${ }^{3}$ can be used to distinguish physical and mental entities.

Different from Talmy who focuses on the typology of causation, Comrie discusses different types of causative constructions. Comrie argues that causative constructions involve two parameters: (1) formal typology and (2) semantic typology. Based on the first perspective, there are three types of causative construction: syntactic/periphrastic/analytic

\footnotetext{
${ }^{3}$ Read further about the animacy hierarchy in Comrie (1989) and Whaley (1997).
} 
causatives, morphological causatives and synthetic/lexical causatives. ${ }^{4}$ The first type of causative construction is biclausal in nature while the second and third are monoclausal. Based on the second perspective, Comrie focuses on (i) the distinction between direct causation and indirect causation, and (ii) the degree of the control held by the causee. ${ }^{5}$

Similar to Comrie, Croft (1991) also discusses the distinction between periphrastic and morphological causatives. Croft argues that in a periphrastic causative, two verbs are involved: causal verb and source verb. Croft also notes that periphrastic causative is usually applied to a transitive verb while morphological causative is used with an intransitive verb base. In discussing these types of causatives, Croft emphasizes on the use of animal hierarchy ${ }^{6}$ to differentiate volitional entities from physical entities.

Like Talmy (1976, 2000) and Croft (1991), Dixon (2000) also consider the importance of volition in distinguishing types of causations (see above). As Comrie has proposed, Dixon also uses the terminology of periphrastic causative, morphological causative and lexical causative.

In looking at the Javanese causatives in this research, I will use Comrie and Dixon's terminology in distinguishing periphrastic causatives and morphological causatives. To look at the causation types existing in the Javanese causatives, I will use Talmy's model of causation.

To limit my research, I aim to look at only the functions and usage of the Javanese causative in on-line and editorials. The findings of

\footnotetext{
${ }^{4}$ Read further about these types of causatives in Comrie (1989)

${ }^{5}$ Ibid.

${ }^{6}$ For more detailed explanation about animacy hierarchy, see Croft (1991).
} 
this research are to contribute the description of Javanese causative which is still rare in the references. Therefore, the questions that I will answer in this research is: What are the distinctive features of Standard Javanese causative constructions in editorials and short stories; what is the distribution across genres of these causative constructions; and what are the functional features of the Standard Javanese in editorials and short stories?' To answer these questions, I will base my research on the functional-typological grammar framework in a corpus-based linguistics that I will discuss in the later section.

\section{Functional-typological grammar}

According to Hawkins (1990: 95), while each language is unique and distinct each other, it is possible to observe some regular crosslinguistic patterns of variation and generalization among those languages. Greenberg (1966) discuss this cross-linguistic comparison in a linguistic typology. Greenberg (1966: 73-5) argues that language universals ate the limits on cross-linguistic variation. He argues that universal can be to look at language universals, a comparison among languages can be undertaken. This comparison is aimed to look at the differences among languages. At this point, Greenberg uses an inductive approach to undertake a cross-linguistic generalization. Haspelmath et al. (2001: v) argues that comparison among languages in a linguistic typology reveals patterns and differences among languages, while the study of language universals aims to look at the general patterns existed in all languages.

Chomsky (1972), as Greenberg does, also talks about language universals. However, Chomsky views language universals differently. 
Chomsky uses a deductive approach to look at language universals based on a formal syntactic analysis on a single language.

With two different perspectives above in looking at language universals, I will be following Greenberg's view to see the variation of language structure within languages and not based on a single language as Chomsky has argued.

Turning to functionalism which cannot be separated from typology, Croft (1995: 505) argues that the basic strategy in functionaltypological analysis is:

to examine a correlation between syntax and semantics (or perhaps discourse function), and seek a functional prototype that is found across languages, and construct implicational universals (particularly implicational hierarchies) holding between nonprototypical semantic types and the prototypical ones.

(Croft 1995: 505)

This means that although a particular language may have some specific language properties, it is still possible to compare crosslinguistic major syntactic categories. This comparison can be undertaken by looking at the function of the inflections and the frequency of the words co-occurs in each language.

Like Croft, Givón (2001: 23), the leading scholar in functionaltypological grammar, also argues that functional-typological grammar views that cross-linguistic structural variation can perform the same type of function. This means that languages can code the same function with more than one structural means. However, it should be noted that there is always a constraint which make them different.

Based on the above discussion, both Croft and Givón argue that the relationship between structure and function, and the degree to which 
the relationship is non-arbitrary is the focus in functional-typological grammar (Malihah 2014: 27). Therefore, I adopt this functionaltypological grammar in my analysis because I will analyse the relationship between the structure and the function of the Javanese causative constructions.

\section{Methodology}

To answer my research question (see above), I need examples of the Javanese causative constructions. In order to get the relevant examples, I collected the data from online local newspaper Solo Pos including short stories and editorials. The reason of using Solo Pos as the source of the data is because this newspaper is published in Solo or Surakarta which is the central of Javanese Culture beside Yogyakarta (Poedjosoedarmo, 1968: 58). For this reason, the assumption is that this newspaper uses the standard Javanese in its publication, especially in column Jagad Jawa.

After I collected the data, I annotated each causative construction by labeling several markers: causative markers ( $<$ CAUS $\rangle$ ), transitivity of the verb $(\langle\mathrm{TR}\rangle,\langle\mathrm{ITR}\rangle)$, animacy of the nouns $(\langle\mathrm{HUM}\rangle,\langle\mathrm{NONH}\rangle$, $\langle$ ANIM $\rangle,\langle$ INA $\rangle$ ), and causation types ( $\langle$ PHYS $\rangle,\langle\mathrm{VOL}\rangle,\langle\mathrm{AFF}\rangle$, $<\mathrm{IND}>$ ). To analyze the data, I used two steps. First, I counted all the annotations manually. This is to count the occurrences of every tag in the data in order to analyze the data statistically. Second, I looked at the frequencies of co-occurrence between different grammatical features in the causatives.

To answer my first research question, I will provide the distribution of the four Javanese causative markers across genres in my 
data. For the second question, I will analyze my data by looking at the functional features of the constructions. This analysis is aimed to look at if functional features that exist in the Javanese causatives affect the selection of each causative marker. It is also to look at the verb transitivity. This analysis is based on Talmy's causation type (see above).

\section{Discussion}

The distribution of the Javanese causative across genre

To answer my first question in this research, I present the distribution of the Javanese causatives in editorials and short stories that I collected in table 1 below.

Table 1 The distribution of Javanese causative in editorials and short stories

\begin{tabular}{|c|c|c|c|c|}
\hline Marker & Editorial & \% & Short story & \% \\
\hline -i & 6 & 14.0 & 5 & 13.5 \\
\hline -(a)ke & 16 & 37.2 & 19 & 51.4 \\
\hline -ne/na & 3 & 7.0 & 0 & 0.0 \\
\hline akon & 4 & 9.3 & 0 & 0.0 \\
\hline marahi & 1 & 2.3 & 0 & 0.0 \\
\hline gawe & 5 & 11.6 & 8 & 21.6 \\
\hline njalari & 1 & 2.3 & 0 & 0.0 \\
\hline ndadekake & 7 & 16.3 & 4 & 10.8 \\
\hline marakake & 0 & 0.0 & 1 & 2.7 \\
\hline Total & 43 & 100.0 & 37 & 100.0 \\
\hline
\end{tabular}


Figure 1 The distribution of Javanese causative in editorials and short stories

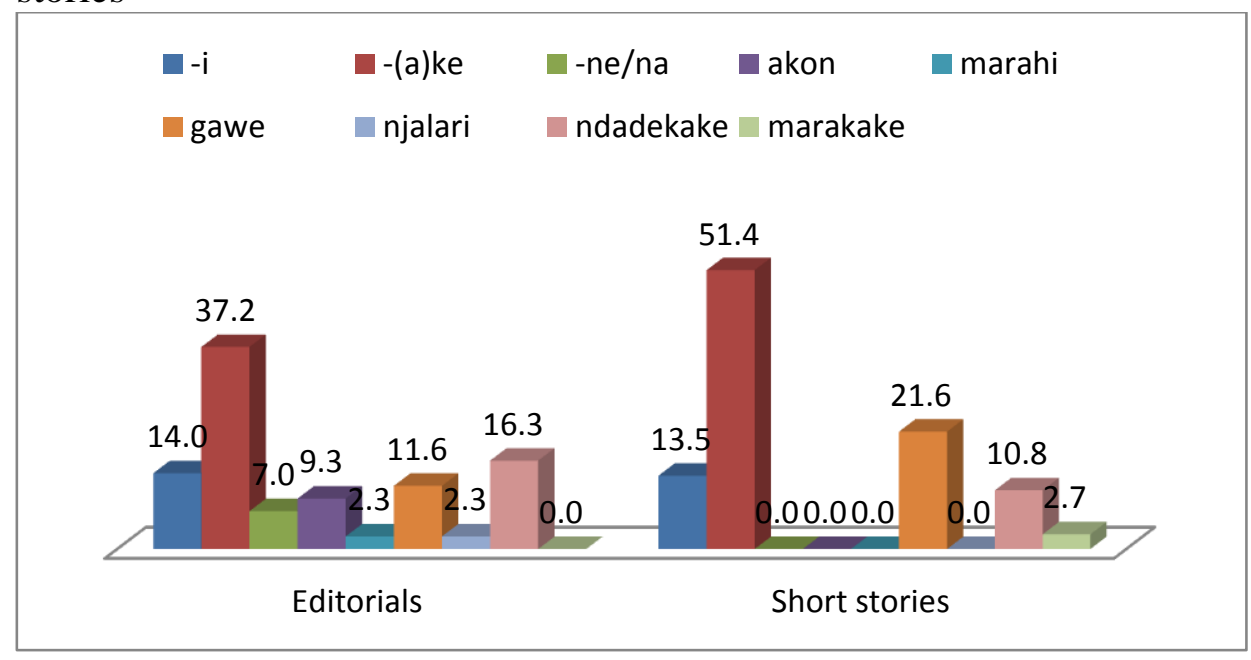

From table 1 and figure 1 it can be seen that there is an important difference between the corpus of editorials and short stories in terms whether $-n a$ and $-(a) k e$ exist in both corpora or not. In editorials, there appears not only the standard Javanese morphological causatives $-i$ and (a)ke but also the non-standard Javanese marker -na (see Malihah 2014). However, in short stories, there were only $-i$ and $-(a) k e$. There might be a genre effect that occurs in these corpora. Although it is actually assumed that the writers of these articles are conscious to use the morphosyntactic features of the standard Javanese $-(a) k e$. The writers of the short stories might have higher consciousness to use the standard Javanese rather than the writers of editorials. Thus, the appearance of $-n a$ in editorials contradicts to what Malihah (2014) has argued that $-n a$ is the dialectal form.

Table 1 and figure 1 also demonstrate that although $-(a) k e$ exists in both editorials and short stories, however, the relative prominence of (a)ke is higher in short stories rather than editorials. The high number of 
$-(a) k e$ in short stories is caused by the absence of $-n a$ which is the equivalent form.

It can also be seen from table 1 and figure 1 that in editorials, more variants of verb of causation in the periphrastic causatives are used: akon 'ask', marahi 'cause', gawe 'make', njalari 'cause' and ndadekna 'cause'. On the other hand, in short stories, there are only three verbs of causation: gawe 'make', ndadekake 'cause' and marakake 'cause'. What is surprising in this data is the use of gawe which contradicts to the canonical Javanese active transitive verb (Robson 2002: 45). Morphologically, an active transitive verb is characterized by the adding of nasal prefix. Thus, the absence of the nasal prefix is not expected to happen in periphrastic causatives in this corpus. Although, Malihah (2014) has found that gawe exists in the spoken data of Javanese Dialect of Kudus. Darmadi et al. (2006: 13) argues that the use of gawe and nggawe in the Javanese periphrastic causatives are seen from the feature of volitionality of the verbs. Therefore, the fact that there is only gawe in my corpus needs further investigation for future research to see the volitional feature of the verbs.

To illustrate the use of gawe in the dataset, consider the example below.

(1) Causative : F6

Apa sing wis di-kekep, sanajan akehe banget, ora bakal

What REL PERF PASS-hold, although much very NOT FUT

bisa gawe mareme nepsu

MOD make satisfy anger

'What has been got, although they are a lot, will never make the anger satisfy'. 
Example (1) shows how gawe is used as verb of causation in periphrastic causative. The canonical Javanese active transitive is .....nggawe mareme nepsu.

\section{A functional analysis of the JDK causative}

There are two causative markers in Standard Javanese: $-(a) k e$ and $-i$ (see Malihah, 2014). However, the non-standard affix $-n a$ also occurs in my dataset. To look at the functions of these three markers and of the periphrastic causative, I analyze each of them based on the transitivity of the verb bases it causativizes, and according to the interaction of each with Talmy's four causation types, which includes looking at semantic features of the causer and causee.

The transitivity of the verb base

Across the 80 examples in my dataset, I examine the transitivity of the verb bases as shown in table 2 and figure 2 .

Table 2 shows that the transitivity of the verb base across the different causative markers is homogenous. For $95 \%$ of the causatives tend to occur with an intransitive verb. Conversely, only $5 \%$ of the causatives tend to occur with a transitive verb. These findings fit to what Davies' (1995: 22) has stated that in Javanese, only intransitive verbs can be causativised by morphological and periphrastic means.

Table 2 The distribution of verb base transitivity across to the standard Javanese causatives 


\begin{tabular}{|l|c|c|c|c|c|}
\hline \multirow{2}{*}{ Marker } & \multicolumn{2}{|c|}{ Intransitive } & \multicolumn{2}{c|}{ Transitive } & Total \\
\cline { 2 - 6 } & N of token & $\%$ & N of token & $\%$ & N of token \\
\hline$-i$ & 11 & 100.0 & 0 & 0.0 & 11 \\
\hline$-(\mathrm{a}) \mathrm{ke}$ & 35 & 100.0 & 0 & 0.0 & 35 \\
\hline- na & 3 & 100.0 & 0 & 0.0 & 3 \\
\hline akon & 3 & 75.0 & 1 & 25.0 & 4 \\
\hline marahi & 1 & 100.0 & 0 & 0.0 & 1 \\
\hline gawe & 11 & 84.6 & 2 & 15.4 & 13 \\
\hline njalari & 1 & 100 & 0 & 0.0 & 1 \\
\hline ndadekake & 10 & 90.9 & 1 & 9.1 & 11 \\
\hline maraake & 1 & 95.0 & 0 & 0.0 & 1 \\
\hline Total & 76 & 95.0 & 4 & 5.0 & 80 \\
\hline
\end{tabular}

I also examine how often active, passive and ergative-like clauses occur alongside the causative in my dataset. I show the distribution of this cooccurrence in table 3 and figure 3.

Table 3 and figure 3 show the occurrence of each causative marker and periphrastic causative in active, passive, and ergative-like clauses.

Table 3 The frequency distribution of the causative's co-occurrence with active, passive, and ergative-like clauses

\begin{tabular}{|l|c|c|c|}
\hline \multicolumn{1}{|c|}{ Marker } & Active & Passive & Erg-like \\
\hline -i & 90.9 & 9.1 & 0.0 \\
\hline -(a)ke & 74.3 & 17.1 & 8.6 \\
\hline -na & 0.0 & 100.0 & 0.0 \\
\hline akon & 0.0 & 75.0 & 25.0 \\
\hline marahi & 100.0 & 0.0 & 0.0 \\
\hline
\end{tabular}




\begin{tabular}{|l|c|c|c|} 
gawe & 84.6 & 7.7 & 7.7 \\
\hline njalari & 100.0 & 0.0 & 0.0 \\
\hline ndadekake & 90.9 & 0.0 & 9.1 \\
\hline marakake & 100.0 & 0.0 & 0.0 \\
\hline All causative & 75.0 & 17.5 & 7.5 \\
\hline
\end{tabular}

Figure 3 The frequency distribution of the causative's co-occurrence with active, passive, and ergative-like clauses as a percentage

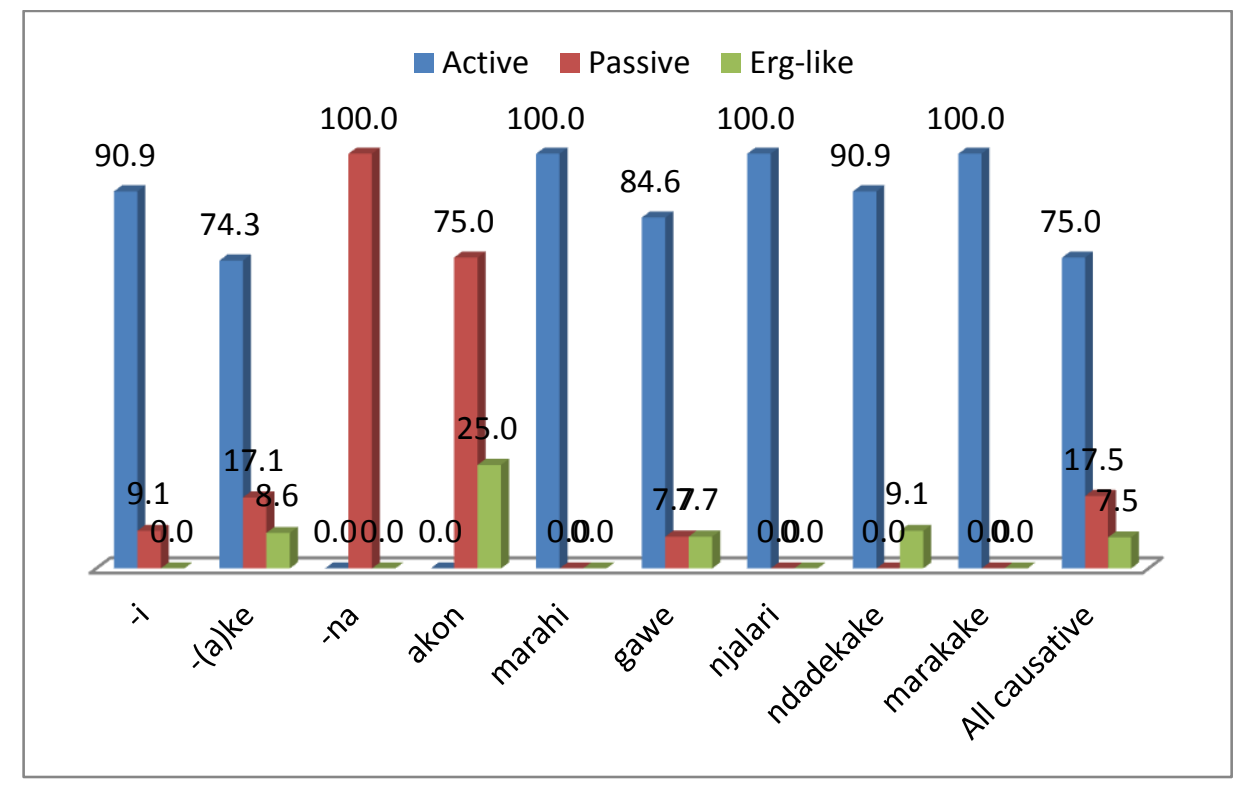

The overall picture is that the difference between active, passive clause and ergative clauses in terms of how often they occur with four causatives is not significant. All types of causative are rare alongside passive clause and very rare with ergative-like clauses. 
Talmy's causation types

In this section, I will start by discussing whether or not there is a relationship between Talmy's causation types and preferences among the different causative markers. Then, I will create a semantic map for the functions of the Javanese causative in editorials and short stories.

The relationship between Talmy's causation types and the different causative markers

In this sub-section, I aim to investigate the Javanese causative in editorials and short stories based on Talmy's causation types, as summarised by Croft (1991:167). As detailed the earlier section, there are four semantic types of causation according to Talmy: inducive, affective, volitional, and physical. For the sake of brevity (Malihah, 2014), I provide table 5 as a reminder of Talmy's causation types.

Table 5. Summary of Talmy's causation types

\begin{tabular}{|l|l|l|}
\hline \multicolumn{2}{|c|}{ Animacy of } & \multirow{2}{*}{ Type of causation } \\
\cline { 1 - 2 } Causer & \multicolumn{1}{|c|}{ Causee } & \\
\hline+ & + & Inducive \\
\hline- & - & Volitional \\
\hline- & + & Affective \\
\hline
\end{tabular}

I present the distribution of causation types across different causative constructions in table 6. 
Table 6 The distribution of the JDK causative markers across Talmy's causation types

\begin{tabular}{|c|c|c|c|c|c|c|c|c|c|c|}
\hline \multirow{2}{*}{ Marker } & \multicolumn{2}{|c|}{ Inductive } & \multicolumn{2}{|c|}{ Volitional } & \multicolumn{2}{|c|}{ Affective } & \multicolumn{2}{|c|}{ Physical } & \multicolumn{2}{|c|}{ Total } \\
\hline & $\begin{array}{c}\mathrm{N} \text { of } \\
\text { tokens }\end{array}$ & $\%$ & $\begin{array}{c}\mathrm{N} \text { of } \\
\text { tokens }\end{array}$ & $\%$ & $\begin{array}{c}\mathrm{N} \text { of } \\
\text { tokens }\end{array}$ & $\%$ & $\begin{array}{c}\mathrm{N} \text { of } \\
\text { tokens }\end{array}$ & $\%$ & $\begin{array}{l}\mathrm{N} \text { of } \\
\text { tokens }\end{array}$ & $\%$ \\
\hline$-i$ & 2 & 18.2 & 5 & 45.5 & 2 & 18.2 & 2 & 18.2 & 11 & 100.0 \\
\hline$-(a) k e$ & 10 & 28.6 & 10 & 28.6 & 6 & 17.1 & 9 & 25.7 & 35 & 100.0 \\
\hline -na & 0 & 0.0 & 0 & 0.0 & 3 & 100.0 & 0 & 0.0 & 3 & 100.0 \\
\hline akon & 2 & 50.0 & 1 & 25.0 & 1 & 25.0 & 0 & 0.0 & 4 & 100.0 \\
\hline marahi & 0 & 0.0 & 0 & 0.0 & 1 & 100.0 & 0 & 0.0 & 1 & 100.0 \\
\hline gawe & 0 & 0.0 & 4 & 30.8 & 4 & 30.8 & 5 & 38.5 & 13 & 100.0 \\
\hline njalari & 0 & 0.0 & 0 & 0.0 & 0 & 0.0 & 1 & 100.0 & 1 & 100.0 \\
\hline ndadekake & 1 & 9.1 & 1 & 9.1 & 6 & 54.5 & 3 & 27.3 & 11 & 100.0 \\
\hline marakake & 1 & 100.0 & 0 & 0.0 & 0 & 0.0 & 0 & 0.0 & 1 & 100.0 \\
\hline Total & 16 & 20.0 & 21 & 26.3 & 23 & 28.8 & 20 & 25.0 & 80 & 100.0 \\
\hline
\end{tabular}

Figure 5 The distribution of the JDK causative markers across Talmy's causation types as a percentage

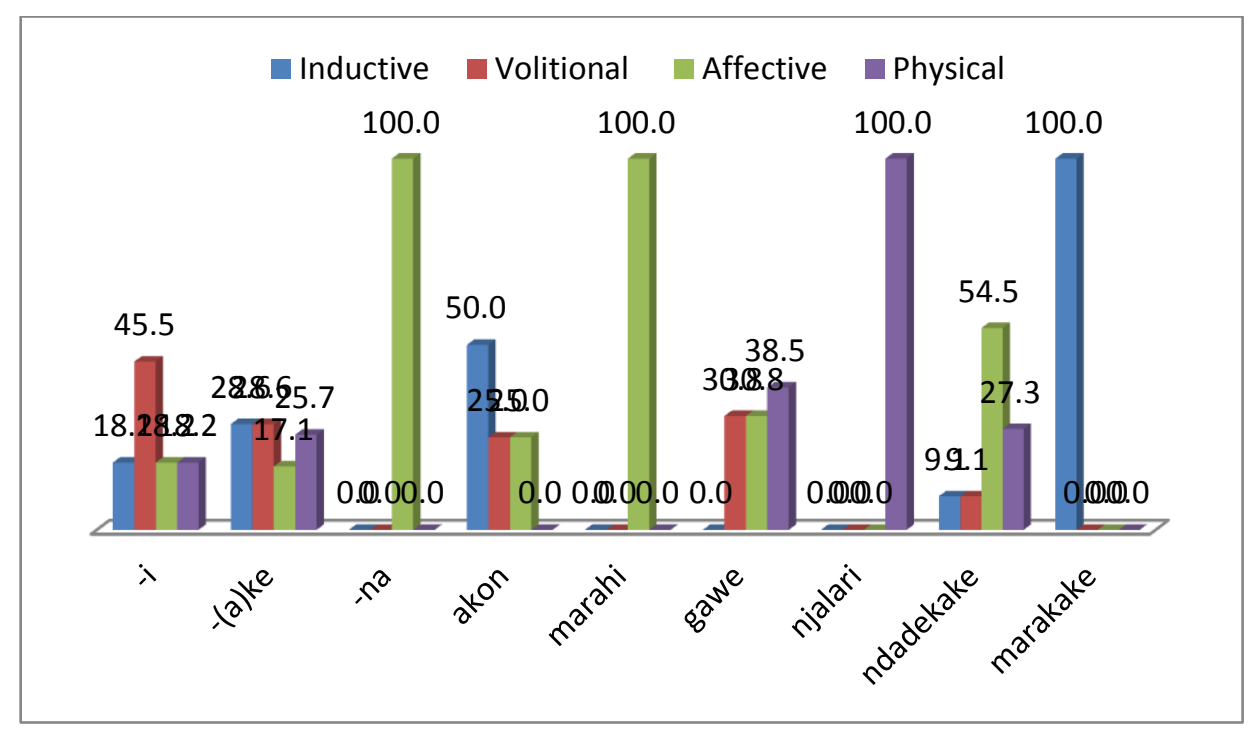


The overall points considering all causatives together (i) the frequencies of all causation types to occur with each causative marker are not consistent; (ii) frequencies of all causatives to prefer Talmy's causation types are approximately equal; (iii) inductive and volitional are approximately equally frequent in $-i$, -(a)ke, gawe and ndadekna; (iv) inducive is absent in -na, marai, gawe, njalari and in marakake, which is only 1 example is an inducive; (v) affective are the only causation type used in $-n a$ and marai.

Table 6 also shows how causation types interact with different markers. If we look at the column in this table, we see that the instances of the four causation types are equally frequent. This means there is no preference for a particular causation type to occur in a particular marker or type of causatives. This contradicts to Malihah's (2014: 332) finding which shows that causation types influences types of causative. However, she needs more data to develop her suggestions due to her limited number of data.

An instance for the use of inducive causation with-(a)ke is shown in example (2) below.

(2) A1 Causative with -(a)ke in an inducive

Dene pelatih-e sawijining nom-nom-an aran

Sugeng

Although trainer-DEF one youth-youth-RED name

Sugeng

sing di-tekak-ake adoh-adoh saka wewengkon Blitar

REL PASS-come-CAUS far-far from place Blitar 
'Although the trainer has made Sugeng come from far away, Blitar.'

Example (2) shows the use of $-(a) k e$ in a causative construction. The non-causative is Sugeng teka adoh-adoh saka wewengkon Blitar. The equivalent non-causative is shown in an active corresponding to the passive in (2). The causee Sugeng is animate and the causer pelatihe which is also animate. Thus, the two nouns which are animate here confirm that this is an example of an inducive causation.

\section{Conclusion}

The aim of this study is to contribute the literature of Javanese causatives. I have fulfilled this aim by answering the question: What are the distinctive features of Standard Javanese causative constructions in editorials and short stories; what is the distribution across genres of these causative constructions; and what are the functional features of the Standard Javanese in editorials and short stories?'

I have shown that the distribution of each construction across genres varies. Editorials have more various causatives used, for example the existence of $-n a$, akon, marahi, and njalari. However, there is still a tendency that $-(a) k e$ is the most prominent variant occurs in both editorials and short stories. This might be because both data are written in which the assumption is that the writers of these articles are aware of the use of standard Javanese causative - (a)ke.

I also found that gawe exists in both editorials and short stories. This finding contradicts to the canonical rule of active verb argued by Robson (see above). 
Turning to my finding on verb transitivity, I found that causative tends to occur with intransitive verb. This finding fits to Davies (see above). Likewise, all causative also prefers to occur in active clauses.

Dealing with Talmy's causation types, I found that $\mathrm{s}$ frequencies of all causatives to prefer Talmy's causation types are approximately equal. However, looking at each marker to occur with a particular causation type is not consistent.

Although I have made a contribution to knowledge on Javanese grammar, however this research needs to into detail on every possible questions and findings. Therefore, this paper also needs further questions remain to be answered with future research.

\section{References}

Chomsky, N. 1972. Language and Mind. In Cashdan, A and Grudgeon, E (eds.). Language in Education. London: Routledge \& Kegan Paul.

Chomsky, N, Belleti, A and Rizzi, L (eds.). 2002. On Nature and Language. Cambridge: Cambridge University Press.

Comrie, B. 1989. Language Universals and Linguistic Typology: Syntax and Morphology (second revision). Oxford: Blackwell and Chicago: University of Chicago Press.

Comrie, B. 2001. Different view of language typology. In Haspelmath, M, König, E, Oesterreicher, W and Raible, W (eds.). Language Typology and Language Universals: An International Handbook. Volume 1. Berlin: Walter de Gruyter.

Conners, T. 2008. Javanese Tengger. PhD dissertation: Yale University. 
Croft, W. 1991. Syntactic categories and grammatical relations. The cognitive organization of information. Chicago: University of Chicago Press.

Croft, W. 1995. Autonomy and Functionalist Linguistics. Language 71(3): 490-532.

Croft, W. 2001. Typology. In Haspelmath, M, König, E, Oesterreicher, $\mathrm{W}$ and Raible, W (eds.). Language Typology and Language Universals: An International Handbook, volume 2. Berlin: Walter de Gruyter.

Croft, W. 2012. Verbs: Aspect and causal structure. Oxford: Oxford University Press.

Dardjowidjojo, S. 1974. The role of overt markers in some Indonesian and passive sentences. Oceanic Linguistics 13(1): 371-389.

Darmadi, K, Laila, M, Harun, JP and Sumarlam. 2006. Aspek morfoleksikal dan tipologis dalam kausatif bahasa Jawa dan bahasa Sunda. Jurnal Penelitian Humaniora 11(1): 1-22.

Davies, W. 1995. Javanese Adversatives, Passives, and Mapping. Journal of Linguistics 31(1): 15-51.

Dixon, RMW. 2000. A typology of causatives: form, syntax and meaning. In Dixon, RMW and Aikhenvald, A (eds.). 2000. Changing valency. Case studies in transitivity. Cambridge: Cambridge University Press.

Givón, T. 1984, 2001. Syntax. Volume I. Amsterdam: John Benjamins.

Greenberg, JH. 1966. Some universals grammar with particular reference to the order of meaningful elements. In Greenberg, JH (ed.). Universals of languages. Second edition. Cambridge, MA: MIT. 
Haspelmath, M, König, E, Oesterreicher, W and Raible, W (eds.). 2001. Language typology and language universals: An international handbook. Berlin: de Gruyter.

Hawkins, JA. 1990. A parsing theory of order universals. Linguistic Inquiry 21: 223-261.

Himmelmann, NP. 1996. Demonstrative in narrative discourse: a taxonomy of universal uses. In Fox BA (ed.). Studies in anaphora. Amsterdam: Benjamins.

Malihah, N. 2014. Valency-changing constructions in the Javanese dialect of Kudus. A PhD thesis: Lancaster University

Poedjosoedarmo, S.1968. Javanese speech level. Indonesia 6: 54-81.

Rahayu, YE and Listiyoroni, A. 2013. Sikap bahasa wanita karir dan implikasinya terhadap pemertahanan bahasa Jawa di wilayah Yogyakarta. Litera 9(2): 122-133.

Robson, S. 2002. Javanese grammar for students. Revised edition. Clyton: Monash Asia Institute.

Rukiah, 2010. Ragam bahasa remaja puteri dalan percakapan informal di kampus UPI Tasikmalaya. Jurnal Sang Guru 1(2): 79-83.

Shibatani, M. 1976. The grammar of causative constructions: a conspectus. In Shibatani, M (ed.) Syntax and semantics 6: the grammar of causative constructions. New York: Academic Press.

Talmy, L. 1972. Semantic Structures in English and Atsugewi. PhD dissertation. Berkeley: University of California.

Talmy, L. 1976. Semantic causative types. In Shibatani, M (ed.) Syntax and semantics 6: the grammar of causative constructions. New York: Academic Press. 
Talmy, L. 1985. Force dynamics in language and thought. In Eilfort, WH, Kroeber, PD and Peterson, KL (eds.). CLS 21. Papers from the Parasession on Causatives and Agentivity at the Twenty-First Regional Meeting of the Chicago Linguistics Society. Chicago: Chicago Linguistic Society

Talmy, L. 1988. Force dynamics in language and cognition. Cognitive Science 12(1): 49-100.

Talmy, L. 2000. Toward a cognitive semantics. Volume I: concept structuring systems. Cambridge, MA: MIT Press.

Wedhawati, Nurlina WE, Setiyanto E and Sukesti R. 2006. Tata bahasa Jawa mutakhir. Yogyakarta: Penerbit Kanisius. 